\title{
The Argentine portion of the soybean commodity chain
}

Maria Jose Haro Sly ${ }^{1}$

ABSTRACT Since the 1990s the soybean crop has increased in the Southern Cone of Latin America (LA). During this time, Argentina, Brazil, Uruguay, Bolivia and Paraguay have become soybean producers. This phenomenon was influenced by the rising soybean demand from China for use in animal feed as the country changed its diet patterns. South American soybean exports to China constitute an important percentage of the bilateral commerce. Basically, two views can be identified with regard to China's relations with LA countries. One of them emphasizes opportunities for building mutually beneficial relations and underscores the economic complementarity between both regions. Yet, the critical literature on China and Latin American relations draws attention to the contradictions of this process by highlighting the deepening of neo-extractivism and the expansion of the agricultural frontier. Describing the Argentine portion of the soybean commodity chain this paper will present data to support this critical literature. It depicts the actors, strategies and the degree of monopolization of each of the nodes of soybean production based on secondary data. The article's key findings are as follows: (1) there is high monopolization and foreignization of soybean production and commercialization; (2) as China has become a global player in genomics and agrochemicals, it has reproduced the same patterns as the core countries; (3) despite the win-win diplomatic statements of the People's Republic of China, there are important asymmetries in trade, and the Argentine deficits have continually increased; (4) by expanding GM soybean production, Argentina has augmented the concentration of land, primarization and transnationalization of the economy and monoculture; (5) the Cristina F. de Kirchner progressive government failed to stop soybean expansion, and with the drop of the economic growth rate that is associated with the fall of commodity prices combined with the restriction of access to international credits, the government was put in check by various fronts. The distributive conflict contributed to the increasing social confusion that led to a right wing recovery in 2015 . Therefore, this article shows that China's increasing trade with Argentina in the soybean sector follows the existing structure of the global commodity chain and does not offer much space for progressive change in Argentina's political economy. The data that are presented demystify Chinese win-win statements and counter expectations about China as an alternative globalizer that would bring more benefits to the global South than traditional core countries have.

\footnotetext{
${ }^{1}$ Federal University of Santa Catarina International Relations, Florianopolis, Santa Catarina, Brazil Correspondence: (e-mail: maria.haro@posgrad.ufsc.br)
} 


\section{Introduction}

ince the end of the 1970s the People's Republic of China (PRC) has been growing at an unprecedented scale. The emergence of China in the world economy led it to become the second greatest economic power in 2014, following the United States (World Bank, 2016). China not only has the highest record of sustained economic growth, but it also has the world's largest population, with almost 1.35 billion people (one-fifth of the world population). An important number of academic studies note the relationship between economic growth and changes in diet in terms of amount, composition and quality (Regmi et al., 2001; Ishida et al., 2003; Jones et al., 2003; Wang and Zhou, 2005, and Liu et al., 2009). The development process in China, the growing industrialization, the increase in the GDP per capita and urbanization have led to a change in diet and food consumption patterns. Zhou et al. (2012) show how China has increased its consumption of meat, eggs, milk, and sugar and diminished its grain consumption as the GDP per capita has increased. Thus, the PRC has become the world's largest food producer as well as the largest food consumer in volume. These increasing changes in food consumption present an important challenge to China given that the country has only approximately $8-10 \%$ of the world's arable land. In China, the rising demand of soybeans, which are used in animal feed (mostly pork meat production) and edible oil, the technological advancements in agriculture and the rise in soybean prices have led to an expansion in production. There has been an overall increase in the world soybean harvested area: from 20 million ha in 1960 to 120 million ha in 2013 (FAO, 2016).

Chinese economic dynamism has accelerated the process of internationalization through the "going out policy", which was highly motivated by the pursuit of raw materials, food and natural resources to sustain industrial activity. As a result of increased Chinese demand, soybeans have become the leading commodity that is produced in the Southern Cone. Thus, the soybean case is a representative example to facilitate the understanding of the relationship between China and South America, where Brazil, Argentina, Paraguay, Uruguay and Bolivia are soybean producers. I will concentrate on the Argentine case as a high rate of the country's harvested area is planted with soybeans, the Argentine export patterns to China are highly concentrated on soybeans, and the country is also the leading world soybean oil and soy meal producer (USDA, 2015).

The PRC's relationship with Latin America has sparked debate in academia, governments, and the general public. In general terms, two views can be identified with regard to China's relations with Latin American countries. One view, which is mostly sustained by the Chinese and Argentine governments, emphasizes opportunities for building win-win or mutually beneficial relations. In addition, academic works suggest the economic complementarities between both regions (with the exception of Mexico). The idea is that China's growing demand for raw materials will present opportunities for South American countries. The increase in Chinese imports influenced the so-called commodity boom, which favoured the state revenues of the Latin American countries as well as the revenues of national and transnational companies. (Lederman et al., 2006a, b; BlázquezLidoy et al., 2007). Richardson (2009), based on O’Donnell (1978), also indicates that by expanding its soy exports, Argentina broke the historical wage-good cycle ${ }^{1}$. The author links the export complex to the domestic political process and labour wages. Traditionally, Argentina's main exports (beef and wheat) have been consumed domestically. For Richardson (2009), soy exports open the possibility of increasing exports without affecting the domestic supply of wage goods. Beef and wheat are less relevant as sources of foreign exchange, and the government can selectively restrict or discourage their export, thereby increasing real wages without provoking a balance-of-payments crisis as they can count on the soybean revenues. Nevertheless, Argentina's deficit has increased; the soybean expansion and the government restrictions on exports of cattle and wheat have caused a drop in these sectors, which has thus affected local production and indirectly influenced domestic consumption (CRA, 2015; Strada and Vila, 2015). Furthermore, the high tendency to implement a monoculture system has critically affected the balance-ofpayment with the end of the commodity boom, as the country has become highly dependent on volatile transnational finance and investment capital's defining of commodity prices, which has thus brought to bear the full spectrum of financial speculation characteristics of the so-called global casino, as Robinson (2008) suggests.

However, the critical literature on Chinese and Latin American relations (Nacht (2012); Jenkins and Dussel (2009), Svampa (2013) draws attention to the contradictions of this process, among them, the deepening of neo-extractivism and the expansion of the agricultural frontier, which results from the growth in the Chinese demand for food and natural resources. This perspective describes it as the reproduction of a centreperiphery relationship. Although these authors recognize that China represents to the region a balance of power that limits United States and Europe presence, they also note that China represents a threat to national industries and an increasing reprimarization of the economy. In the same way, some authors have referred to these relations as a "Commodity Consensus", paraphrasing the "Washington Consensus", in that they consider this relationship with China to be completely based on neo-extractivist activities, enormous commercial asymmetries, the loss of food sovereignty, and environmental degradation, among other factors (Svampa, 2013; Slipak, 2013, 2014, Slipak and Bolinga, 2015).

This article is grounded in this last tradition by describing the Argentine portion of the soybean commodity chain (APSCC) using the framework of a world-systems approach (Hopkins and Wallerstein 1977, 1986, 1994; Arrighi and Drangel, 1986). Thus, this article will show that China's increasing trade with Argentina in the soybean sector follows the existing structure of the global commodity chain and does not offer much space for progressive change in Argentina's political economy. I will also present data to refute the expectations of China as an alternative globalizer that could bring more benefits to the global South than has been done by traditional core countries. The paper's key findings are as follows. (1) There is a high monopolization and foreignization of soybean production and commercialization. (2) As China has become a global player in genomics and agrochemicals, that is, buying Nidera, Syngenta, Atanor and producing $40 \%$ of the world's supply of generic glyphosate, the PRC reproduces the same patterns as core countries. Thus, China does not present a sustainable model for world food production. (3) Despite the friendly diplomatic statements of the PRC, there are important asymmetries in trade, Argentine exports are highly concentrated in few raw products, and trade deficits have constantly increased. (4) By expanding GM soybean production, Argentina has radicalized the trends that began in the 1970s and grew in the 1990s: the concentration of land, the primarization and transnationalization of the economy, the development of monoculture, the displacement of the peasantry, increasing the dependency on volatile commodity prices and threatening the environmental and human health. (5) The Cristina F. de Kirchner (CFK) progressive government has failed to stop soybean expansion, and as a result of the drop in the economic growth rate that is associated with the downfall of commodity prices 
combined with the restriction of access to international credits, the government has been put in check by various fronts. The distributive conflict has increased and contributed to the social confusion that led to a right wing recovery in 2015, which resulted in the election of Mauricio Macri as the Argentine President, which is seen as a new neoliberal lunge.

(1) Commodity chains: the soybean case. What do soybeans mean for Argentina? Who gets what?. At the beginning of the 21st century, there was an increase in trade between the PRC and the Republic of Argentina. During the past decade, the PRC has become the second largest Argentine commercial partner, after Brazil. According to the ECLAC, the sum of the five leading products that are exported from Argentina to China make up $85 \%$ of the total exported goods ( $58 \%$ soybeans, $10 \%$ soy oil); that is to say, approximately $70 \%$ of the Argentine exports to China are concentrated in soybeans or their derivatives. The Argentine balance of payments with China has been highly affected by the drop in commodity prices ${ }^{2}$. Although exports increased $84 \%$ in terms of volume from 2012 to 2015, the income in millions of dollars for the same period was $30 \%$. Thus, Argentina did not solve the dilemma of a commodity export orientation, whereby primary producer countries suffer the economic vulnerability that is related to the volatility of commodity prices (Prebisch, 1964).

It is important to demystify the friendly win-win Chinese diplomacy statements that have been made in the bilateral agreements between the PRC and Argentina ${ }^{3}$. In contradiction to them, the bilateral commerce presents an increasing deficit in the balance of payments; from 2008 to 2014, Argentina accumulated US\$ 18.2 billion in deficits with the PRC (INDEC, 2015). Considering the period from 2011 to 2015, it is clear that although China is the first worldwide soybean importer and soymeal and soy oil consumer (USDA, 2015), the PRC does not appear on the list of leading soy meal importers, not even the top 10. Regarding soy oil imports, China is in second place following India. However, while India has increased its imports year by year, China has decreased its soy oil imports. At the same time, China is increasing its own soy oil production (USDA, 2015). Thus, it is clear that the Chinese preference is to buy raw materials with less value in favour of its own soy crushing industry (USDA, 2015). Another aspect of Chinese protectionism is the implementation of a $9 \%$ tariff for soy oil imports (although it is $10 \%$ less than the US tariff, which is currently 19\%) (Fried, 2012).
The story of soybean production in Argentina began in the 1970s, and production increased rapidly in the 1990s, when genetically modified (GM) soybean varieties began to be commercialized in $1996 .^{4}$ This type of GM soybean was engineered to be herbicide resistant (primarily to the RoundUp Ready brand glyphosate). Today, $63 \%$ of the harvested Argentine land is planted with soybeans, as is shown in Fig. 1. This commodity has very low domestic consumption, and its export revenues represent $31.8 \%$ of Argentina's export income (INDEC, 2016).

In this section, I will analyse the distribution of gains in the Argentine portion of the commodity chain ${ }^{5}$ (Hopkins and Wallerstein, 1977,1986; Arrighi and Drangel (1986). According to Hopkins and Wallerstein (1994) a commodity chain describes the network of processes and labour that generate a product. Each of these processes constitutes a "node" in the chain, and whoever commands the majority of the activities that generate a surplus establishes the core. In this conception, profitability is directly related to the degree of monopolization. What the authors essentially mean by core-like production processes is those processes that are controlled by quasi-monopolies. By tracing the networks of commodity chains (CC), one can track the ongoing division of labour and the documentation of the patterns of the capitalist world economy (Hopkins and Wallerstein, 1994). Thus, world-system theorists are interested in how CC structures reproduce a stratified and hierarchical world-system (Bair, 2005). By describing the segments of the production agents and paying considerable attention to the extent of monopolization in each of the nodes, the description of this CC will shed light on "who gets what" in the Argentine soybean production. An entire scheme of the Argentine portion of the soybean commodity chain is presented on page 5 , and the following explanation describes the actors and the degree of monopolization of the "boxes".

A report of the National News Agency TELAM (2014) explains that a soybean yield is measured per quintals that are harvested per hectare. The average in Argentina is 30qq/Ha. Figure 2 explains the distribution of income considering a soybean price of USD540 per ton and a $400 \mathrm{Ha}$ farm, which sums a gross earnings of $\$ 628.800$. Of the $\$ 628.800,35 \%$ goes to the state $(\$ 220.000)$; $43 \%$ goes to the renter $(\$ 270.000)$ and $22 \%$ goes to the owner of the land $(\$ 138.000)$. The soybean profitability is $34 \%$, which makes it one of the most profitable businesses in Argentina (TELAM, 2014).

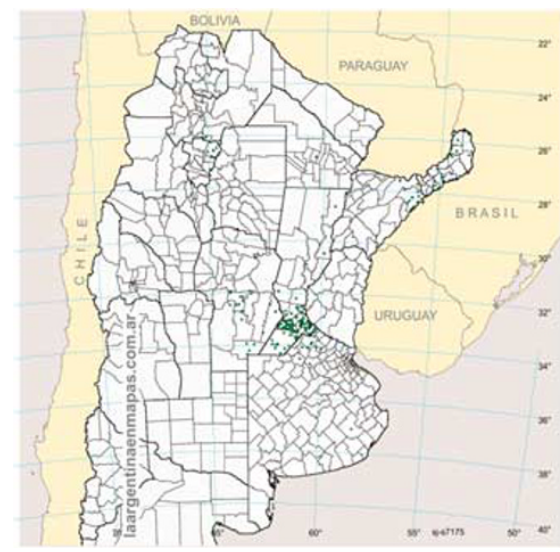

$1970-1975$

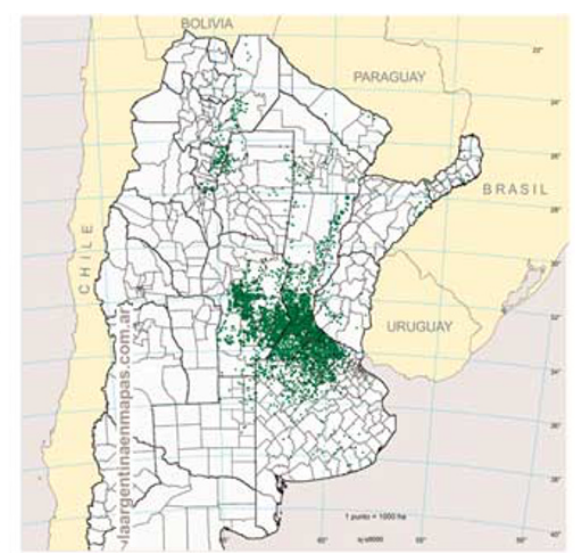

1991-1995

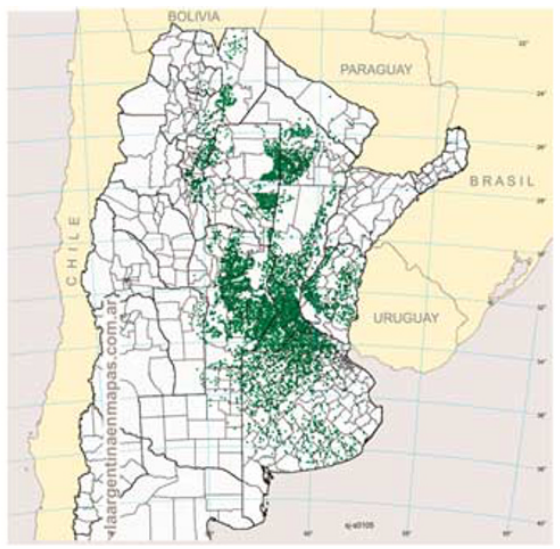

2006-2010

Figure 1 | Soybean harvested Area in Argentina shows the soybean crop expansion from the 1970s to 2010. This figure is not covered by the Creative Commons Attribution 4.0 International License. Reproduced with permission of CONICET Consejo Nacional de Investigaciones Científicas y Técnicas, IMHICIHU, Buenos Aires, 2012 (consulted 03/01/2015); copyright (C) CONICET, all rights reserved. 


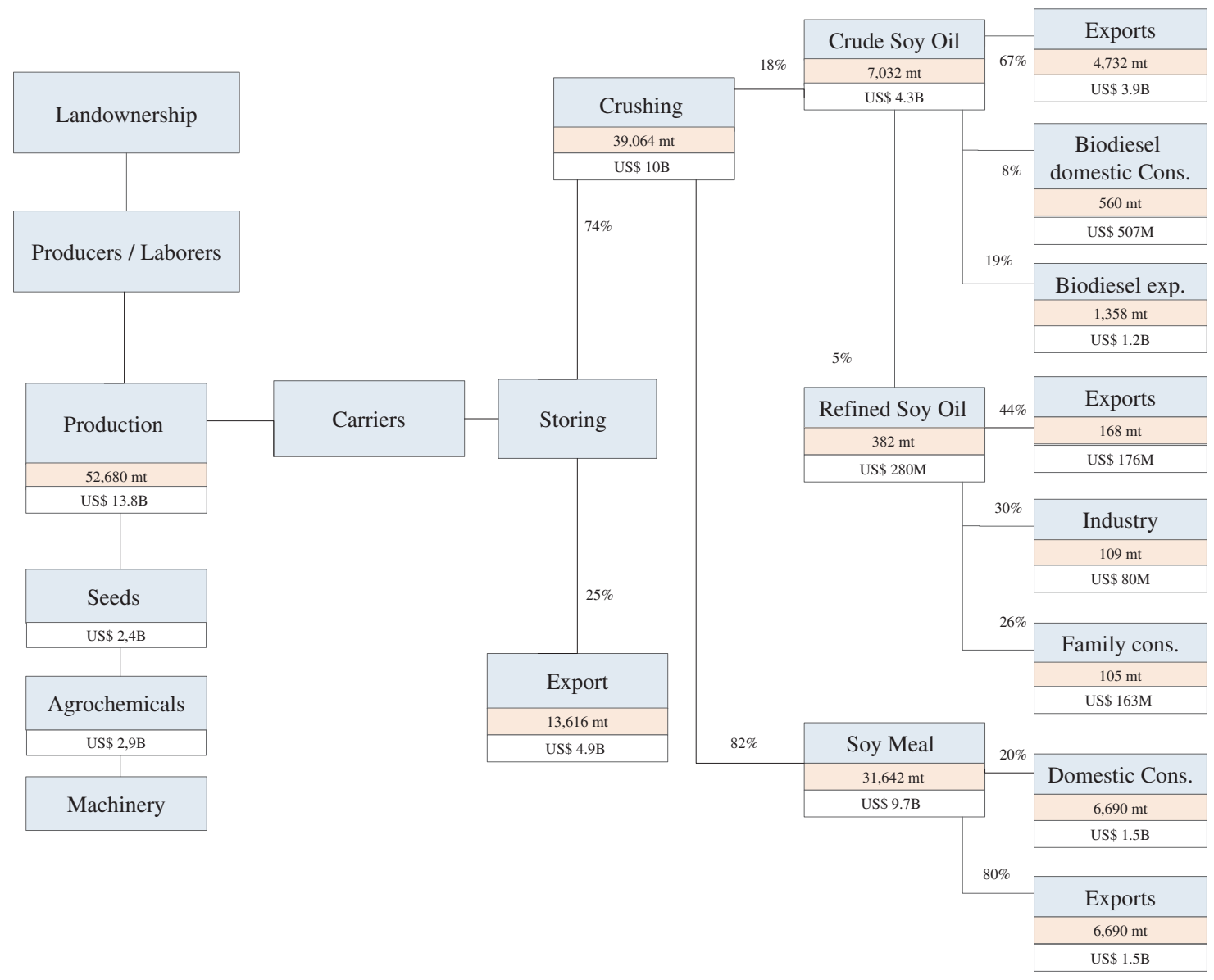

Elaborated by the author based on MECON (2011), Dabat and Paz (2013). Note: Data correspond to 2010. Percentage of the Volume.

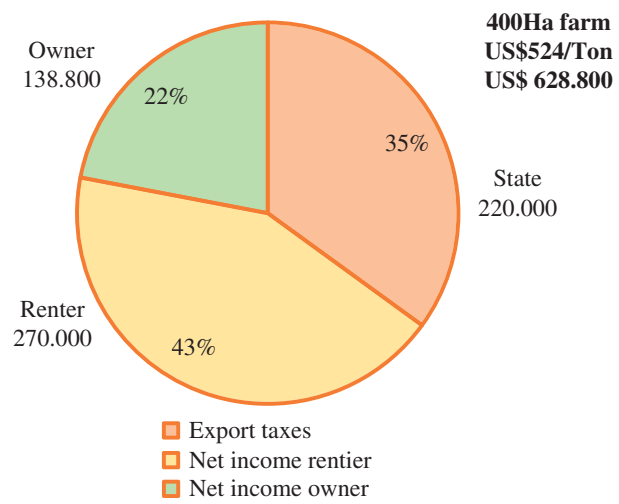

Figure 2 | Distribution of gains among the states, renters and landowners. Illustrates the distribution of gross profits for the soybean case. Source: Elaborated by the author adapted from data provided by TELAM, 2014.

Today, despite the reduction in soybean prices (\$ 329 in March $2016^{6}$ ) soybean farming is still one of the most profitable activities in the country ${ }^{7}$ (Infocampo, 2016, 2017).

According to Ainsuain (2008), the census of 1903 shows that 35 traditional landowning families owned most of the land. The census of 2008 indicates that 30 of these 35 same families still own a large percentage of land. Among them is the Anchorena family, with 40,000 Ha, and Gómez Alzaga with 60 thousand Ha.
In the 2002 census, the 936 most powerful landowners had 35.5 million Ha; however, 137.021 producers had 2.2 million Ha. Just four landowners have roughly the same amount of land as the small producers, which is 1.85 million $\mathrm{Ha}$ (a territory that is comparable to that of Belgium): Benetton (900,000 Ha), Cresud $(460,000)$, Bunge $(260,00)$ and Amalia de Fortabat $(220,000)$.

The tendency towards land concentration has worsened over time $^{8}$. Agricultural censuses from 1952 to 2008 in Argentina show a sharp decline in farms that are owned by individuals and an increase in the acreage sizes of farms that are owned by traditional landowning families and other larger players in agriculture investment such as transnational companies. A total of $22 \%$ of the soybean revenue goes to the landowner. Because land ownership is highly concentrated, the landowners are the main beneficiaries in the soybean trade.

There are several ways in which the land concentration process occurred in Argentina:

(1) Small producers sold their land: Those without capital to produce for themselves rented out their land to other farmers or planted pools through contractual leasing or sharecropping (aparceria and medieria) (Giancola et al., 2009).

(2) The professionalization of agribusiness: Farmers who owned capital to rent the farms of smaller farmers increased their production. Some farmers diversified their activities by investing in machinery. Others sent their family members for advanced training in university agricultural management programmes so they use they could in turn use the knowledge to professionally run their farms (Grosso et al., 2010). 
Traditional agribusiness families that own large extensions of land generally have a rural background. Their families have been in agribusiness for at least two generations. These families improved their business management in agriculture by investing in different activities in the commodity chain such as offering consulting services and producing agrochemicals (Grosso et al., 2010).

(3) New actors: The new types of "tenants" are the planting pools and the agricultural investment funds. The formers are generally an association of producers (owners or contractors) who join together to negotiate services and prices to commercialize their grains or to exercise control over the whole production process. There are different types of aggrupation and contracts, and most of them follow a joint venture model. They have different sizes of planting pools, which range from a thousand to 50,000 Ha. The agricultural investment funds act in a manner that is similar to any other financial investment fund; the investors invest and leave the management to the administrators. According to Grosso et al. (2010) the investments are at least \$500.000.

(4) The foreignization of the landownership: In Argentina, 15 million ha are owned by foreigners, which is $5.6 \%$ of the territory. This represents a percentage increase in some of the most productive areas (RNTR, 2016). Along the same lines as the core transnational companies, the Chinese companies are buying land in Latin America. According to Inter American

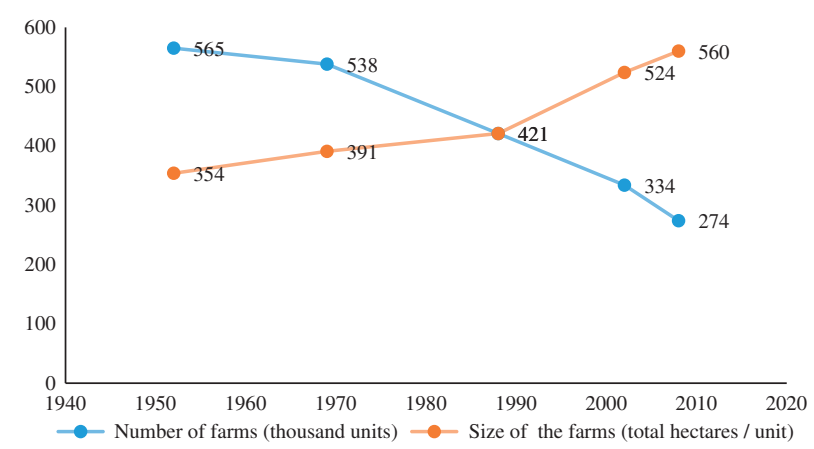

Figure 3 | Concentration of Landownership. Illustrates the concentration of land trend in Argentina. Source: Elaborated by the author based on national Agriculture CENSUS data. Note: Data for $\mathbf{2 0 0 8}$ are preliminary.
Dialog (2015) China planned to buy $444,000 \mathrm{Ha}$ in the Cordoba and Rio Negro Provinces in Argentina. Although these purchases are still not confirmed, or they may have stalled, they correspond to an increasing tendency in Latin America. ${ }^{9}$

Farmers with capital, farming pools and agriculture investment funds have rented more than a $60 \%$ of the land (Telam, 2014). Therefore, the issue of land ownership and the capital to rent large areas determines the incomes of the actors. In Argentina, despite the diversity of the actors, $50 \%$ of the production was controlled by $2.6 \%$ of the total producers in 2010 (Socioenviromental Soybean Observatory, 2014). Figure 3 shows the stratification of the production in terms of volume (tn). Figure 4.

It is important to underscore that "For each $1000 \mathrm{Ha}$, the soybean crop employs 15 workers while for the same size the sugar cane crop employs 350 workers and the citric crop employs 1,300 workers" (Telam, 2014). According to Fascendini (2006) in the Buenos Aires Metropolitan Area 8 of 10 unemployed persons come from the agriculture sector. As soybean farming is highly mechanized, an increase in agribusiness has resulted in the displacement of rural communities to larger cities.

In summary, a high concentration in soybean production by landowners (national and transnational) and producers (national and transnational) implies a high concentration in gains in the soybean chain.

However, of the cost of soybean production that must be subtracted from the $43 \%$ that goes to the renter ( $\$ 220.000)$; part goes to the seed companies, fertilizer companies, machinery sellers, and it is also used to pay for labour, gasoil and service companies.

The GM soybean varieties that began to be commercialized in 1996 in Argentina were fundamental to the increase in the soybean crops worldwide. Monsanto owns the intellectual property rights (IPR) of the Soybean GM and the herbicide. Filomeno (2014) suggests that the powerful and influential Argentine rural producers have pressed the state for cheap access to foreign technology. Thus, the state has a permissive intellectual property regime for the use of seeds. Argentina continues to be the only country that does not pay IPR fees to Monsanto in the Southern Cone. Nevertheless, at the end of 2015, Monsanto initiated the strategy of collecting royalties by using crushers and exporters to charge farmers $\$ 15$ per metric ton. This amount was

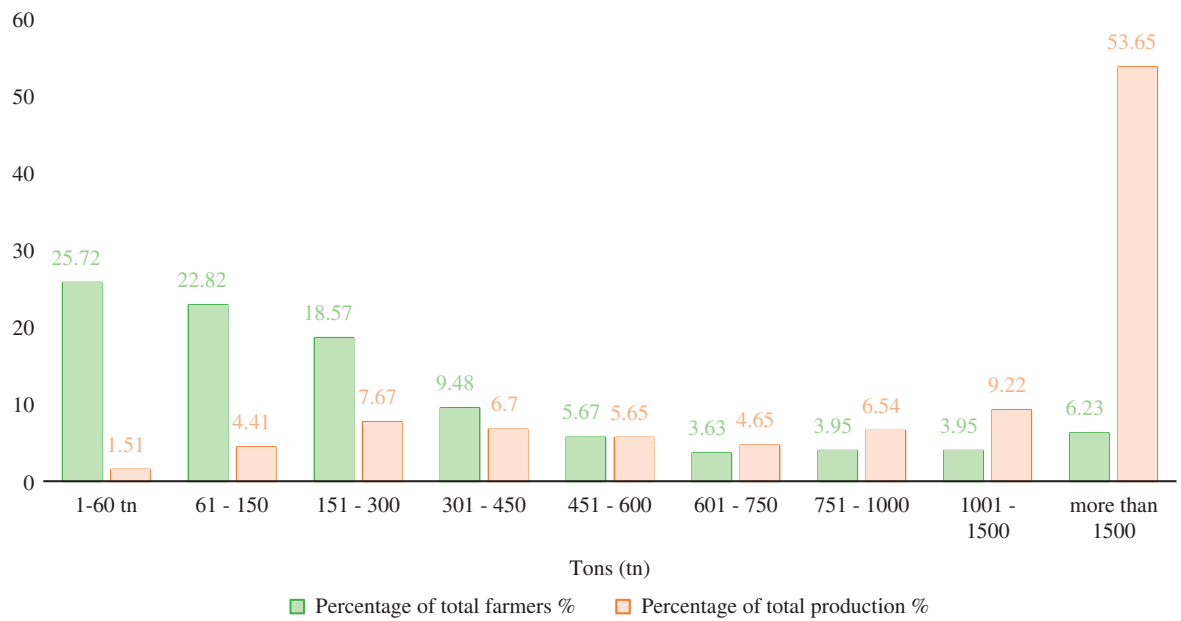

Figure 4 | Stratification of the production. Shows the percentage of soybean production by each of the categories. Source: Elaborated by the author based on statistics provided by Regunaga (2009) and the CENSUS 2008. 
connected to the second generation of GM soybeans, the "Intacta RR2". All of the exporters have signed agreements to collect royalties under the threat that Monsanto will not sign a "biosecurity certificate," which is a condition to export soybeans to China. Thus, export companies included a "biotech clause" in the "forward" contracts for the soybean harvest 2015/2016 that controlled the soybeans under the IPR and not under the Argentine Seed Law (Pagina 12, 2016c; GRAIN, 2015). Conflicts in royalties and the validity of the Seed Law or the IPR continue between seed companies, farmers, exporters and the state.

These GM soybeans were engineered to be herbicide resistant (primarily to the RoundUp Ready brand glyphosate); thus, the incorporation of GMOs and the no-tillage system in the 1990s led to an increase in the use of fertilizers and herbicides. The average of amount of glyphosate that was used in 1996/1997 was 3 litres/ Ha. Notwithstanding, in 2013 Argentinian farmers used 12 litres/ $\mathrm{Ha}$, which was generally potentiated with other herbicides such as graminicides and hormones (Socioenvironmental Observatory, 2014). According to the Argentine Chamber of Agricultural Safety and Fertilizers the principal herbicide in terms of income is Glyphosate (64\%). The main companies that operate in the country are Monsanto-Bayer ${ }^{10}$, Syngenta, BASF, Dow Agrosciences, Advanta, Bayer Cropscience, Nidera, DuPont, Nufarm, Merk and Repsol-YPF. However, in this market there are also some medium-sized local and international firms, which produce and/or import and distribute agro-chemicals (Regunaga, 2009).

In the beginning of the 2000s, Monsanto controlled 65\% of the Argentine glyphosate market and Atanor had 15\% while the rest went to 18 Argentine companies (Pagina 12, 2003). Chinese companies have increased their presence in this node. In fact, glyphosate appears among the 5 leading imported products from China: second in 2006 (\$83 million); second in 2007 (207); first in 2008 (496); second in 2009 (202) (CEI, 2007, 2008, 2009, 2011).

Currently Chinese companies produce $40 \%$ of the world's glyphosate supply and $35 \%$ of the worldwide exports. In 2014, the Chinese company Huapont Nutrichem bought $20 \%$ of the actions of the Albaught LLC group, which controls Atanor (Clarin, 2014). According to Hilton (2012) "The ramp up in industry supply of generic glyphosate by Chinese firms to capitalize on bumper profits not only reduced global prices but hurt margins earned by Monsanto in 2010". In 2001, Monsanto started an anti-dumping case against imports of glyphosate from China to Argentina. This case was not successful because the producers and the government preferred to import from China at a lower cost (Filomeno, 2014).

Figure 5 illustrates the direct cost of soybean production and the cost of tillage, fumigation, seeds and agrochemicals in relation to soybean prices. It is clear how the cost of production is associated with the soybean prices. According to Calzada and Corina (2015), the prices of seeds and agrochemicals are responsible for $20 \%$ of the gross income of producers.

Another important segment is the machinery for the soybean crops. Although there are 1.500 worldwide firms in this sector, 15 companies produce $60 \%$ of the agricultural machinery supply (John Deere \& Company and CNH Global are two of the biggest companies) (Ministry of Finance, 2016). In 2002, the share of agro-machinery production by national manufacturers was $63 \%$, and the transnational share was 37\%, while in 2007 these relationships were $43 \%-57 \%$ and in $200837 \%$ and $63 \%$, respectively. During this period machinery imports increased. In 2011, an ISI policy was initiated, primarily in the tractor and harvester sectors. Nevertheless, Argentina has an important deficit in the balance of payments of the machinery sector as is shown in Fig. 6. In 2014, there was a strong presence of Brazilian importation (50\%), followed by the United States (20\%) (CAFMA, 2015).

According the Giancola et al. (2009), Argentina has better competitiveness in terms of production than its competitors (Brazil and the United States). Nevertheless, Argentina has higher commercializing costs because of transport, storage and export taxes. With regard to transport, $84 \%$ is carried by trucks, $14.5 \%$ by railway and $1.5 \%$ by barges. The exports are transported by ships (90\%) and trucks (7\%) and the remainder by railway and barges. According to Calzada and Corina (2015) the prices of transport account for between $13 \%$ and $23 \%$ of the gross income of the producers in relation to the distance to the harbour.

An important point is that, because of the increasing commercial and diplomatic bilateral relationship between Argentina and China during the Kirchners' presidencies, the PRC signed two major projects in Argentina to finance the development of export infrastructure. They are the Belgrano Cargas Railway, which will connect the principal economic regions to the Buenos Aires Harbour, and the Bi-oceanic Tunnel, which will open a railway that connects Argentina and Chile across the Andes Mountains (Ministry of Foreign Affairs, 2015) ${ }^{11}$

As Soyatech (2016) states, "there are four multinational corporations who dominate the world trade in soybeans (as well as many other commodities). They are Archer Daniels Midland Company, Bunge Limited, Cargill Incorporated and Louis

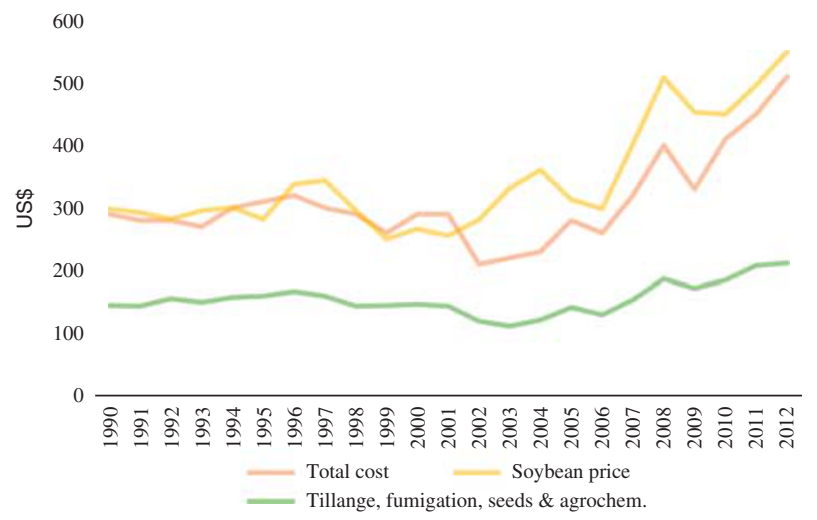

Figure 5 | Soybean prices and direct cost of soybean production. Shows the evolution of soybean prices, the total direct, and the sum of tillage, fumigation, seeds and agrochemicals prices cost from 1990 to 2012. Source: Elaborated by the author based on statistics provided by the World Bank and Márgenes Agropecuarios in Dabat and Paz, 2013.



Figure 6 | Argentine export, imports and balance of payment of agriculture machinery. Shows Argentine exports, imports and balance of payment of agriculture machinery in million US\$ from 2010 to 2015. Source: Elaborated by the author based on statistics provided by the Ministry of Finance (2016). 
Dreyfus Group. These firms also have significant soybean processing interests throughout the world" (2015). Other companies are Itochu Corporation, Marubeni Corporation, Mitsui \& Co. Ltd., Noble Group and Sumitomo Corporation. In Argentina, the soybean trade and commerce are concentrated in approximately 10 companies; some are transnational, while some are national. In the past decade, national cooperatives such as the Argentina Association Cooperatives (ACA) and Argentine Federated Farmers (AFA) have increased their participation in the export sector. According to TELAM (2014), "Today (2014) in grains, the producer participates in $60 \%$ of the investment but $20 \%$ of that produced by that investment, and the one who trades, conversely, keeps $60 \%$ of the income when his participation in the production is 20\%" (Fig. 7.)

With regard to the Chinese presence in the soybean commodity chain, China's stated-owned food group Cofco bought $51 \%$ of the Dutch company Nidera in 2014 (La Nacion, 2014), and in 2016, China's Cofco bought the remaining $49 \%$ stake in the company (Fiancial Times, 2016). In addition, ChemChina bought the Swiss company Syngenta in 2016 (Reuters, 2016). Thus, Chinese state-owned companies are looking to acquire foreign firms to help to secure supplies of commodities; they are investing in logistics, processing, and trading ventures to secure the external food supply (Myers et al., 2015).

According to Regunaga (2009: 15), "There are about 1,200 private firms and 500 cooperatives, who own around $54 \%$ of the total fixed storing capacity of Argentina". The deficit in storage capacity was covered by plastic silos, which in 2007 represented approximately $30 \%$ of the total capacity.

The crushing industry of protein meal and crude vegetable oil is extremely concentrated; 6 firms handle approximately $93 \%$ of the crushing capacity. The crushing industry involves international companies (Cargill, Dreyfus, Bunge, Glencore, Nidera) and some large local firms (Molinos Río de la Plata, Aceitera General Dehesa-AGD, Vicentin). They produce soy oil and soy meal; and some large crushing firms have built bio-diesel plants for the export market. The refining capacity is smaller than the crushing capacity. It is also concentrated in few large firms such as Bunge, Molinos, Vincentin and AGD (Regunaga, 2009). Currently, there are 23 companies that produce biodiesel in the country (MECON, 2011 ), and $22 \%$ of the biodiesel producers account for more than $60 \%$ of the total biodiesel that is produced.

This panoramic description of the APSCC depicts national and transnational actors, their shares, and the revenue flows among

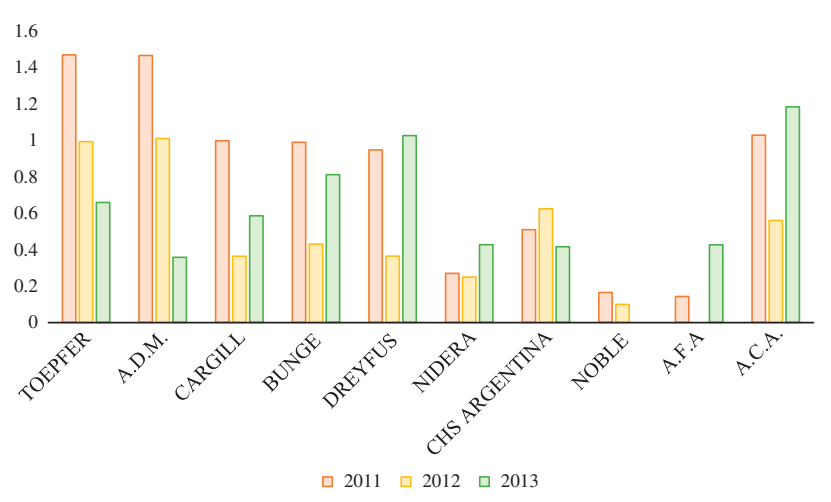

Figure 7 | Soybean Exports by Company. Shows soybean exports by company in Argentina in 2011, 2012, 2013 in thousands of metric tonnes. Source: Elaborated by the author adapted from data provided by TELAM (2014). the chain. To summarize, there is a high monopolization and foreignization of soybean production and commercialization. Although there are no data on the profitability of each of these segments, by offering an idea of the amount of revenue flows and the high degree of monopolization of these segments-mostly by foreign companies-this description shows the patterns of functioning of the world economy. Even though China was not a relevant actor in the past, it is now an important player as it has purchased global player companies and increased its presence in agrochemicals.

(2) The politics of production and exports in Argentina: conflicting disputes. The specific case of soybean production in Argentina has yet to be discussed among scholars. Richardson (2012) discusses taxation in Argentine soy production and suggests that the rural sector withdrew from politics, thus weakening their traditional influence in the state and their strong role in Argentine politics. The author based his argument on the fall of membership in rural associations as a result of their inability to stop taxes on their members' incomes. I would suggest that despite the fall in membership in the organizations, the rural sector is still powerful and wields a great deal of political influence, as seen in the rural conflict in 2008 when the former president Christina Fernandez de Kirchner tried to implement a mobile progressive export tax based on fluctuations in soy prices. Disinformation campaigns by the rural lobby and protests throughout the country caused the presidential coalition to collapse when the vice president cast a vote against the president. Hence, the state failed in its attempt to impose a progressive export tax on a sector where $50 \%$ of the production is controlled by $2.6 \%$ of the total producers (Socioenviromental Soybean Observatory, 2014). The structural conditioning of this rural class based on an agribusiness state is strong. As noted above, between 30 and 35 families have controlled most of the harvested area in Argentina since the 1900s. This agrarian economic elite continues to protect its class interests and supported the election of president Macri in 2015. President Macri's first policy agenda was to end the retention of taxes to agribusiness. In the soybean case, he slashed the tax rate from $35 \%$ to $30 \%$. His administration plans to reduce taxes on soybeans annually until they are completely eliminated (TELAM, 2015). Furthermore, at least 30 officials of the Macri administration have links with the oligopoly of the agribusiness and agro-chemical industry (Greenpeace, 2017).

As Filomeno (2014) has suggested, another argument that shows the power and influence of Argentine rural producers is that they have been influencing the state to obtain cheap access to foreign technology; thus, the state has implemented a seed intellectual property rights regulation that is different to that of Paraguay and Brazil. That allows Argentina not to pay royalties to Monsanto, and it can keep seeds to promote national breeders, to defend its national sector despite the transnationals. The Law of Seeds and Phytogenic Creations was passed in 1973 to promote the development of new national seed breeders such as the soybean HB4, which is a drought-resistant species that was patented in 2015 by Litoral National University, the National Scientific and Technical Research Council (CONICET) and the private Argentine company BIOCERES. The CFK government promoted innovations in the biotechnology sector to improve its gains in the commodity chain; however, at the same time it did not question the existing agricultural model.

With respect to the CFK's progressive government, the state promoted the increase of cooperatives that participate in the export sector in an attempt to "democratize and nationalize" exports. 
Oilseed sales have historically been highly concentrated and with a high level of foreign ownership. However, in recent years, thanks to the action of the State, grain exports recorded a deconcentration of the hands of the major multinationals operating in the country, in favor to the domestic producers' cooperatives. Thus, 82 percent of exports in 2005 were concentrated in 6 companies, and in 2012 , it had spread to ten companies, including for the first time domestic producers cooperatives. Argentine Federated Farmers (AFA) increased its exports from 115,000 tonnes in 2005 to 800,378 in 2013, increased almost 8 fold. In the same way the Association of Argentine Cooperatives (ACA) became in 2013 the fifth largest exporter of grain, relegating Bunge, Nidera and Glencore, with 1,259,944 tonnes" (TELAM, 2014).

In 2011, the congress sanctioned the law 26.737 to control and avoid the foreignization of the land in the future. The law allowed for a maximum $15 \%$ ownership of cultivable land by foreigners and a maximum of $1000 \mathrm{Ha}$ in the most productive area. While the law was not retroactive and did not change the previous ownership deals, it protected against further transnational investment in the area. As soon as Macri's government came to power, this law was weakened to promote transnational investments (La Nacion, 2016; Pagina 12, 2016a).

Robinson (2008) has noted that the social contradictions that are generated by the model, that is, concentration of land, displacement of the peasantry, and contraction of the domestic market, among other factors, have led to heightened social conflict. The author describes this model as being highly dependent of volatile transnational finance and capital, of which a large component involves financial the speculation characteristic of global casino economics. However, Robinson (2008) indicates that the soybean case is not a situation of core-periphery relations of dependency because of the fusion between Argentine capital and the transnational complex that controls worldwide soybean production. I would suggest that Argentina, as a semiperipheric country, developed strategies to fight for an increased share in the commodity chain, and although the well-fused agrarian elite has benefited from this model, the presented data show that the degree of monopolization and foreignization of the soybean production is extremely high. In addition, the transnational and national elites are involved in profits disputes, that is, the soybean IPR case.

Regarding the limits and contradictions to the "commodity consensus", it is important to underscore that the expansion of the agricultural frontier increased the conflicts with indigenous populations in inland Argentina. Currently there are indigenous claims, most of them related to indigenous territories and the pressures of agribusiness companies trying to evict them (Amnesty International, 2016). The soybean crop produces only 15 employees per $1000 \mathrm{Ha}$. As a result, more labourers and their families are migrating to urban cities. Furthermore, as indicated above, the concentration of land is increasing; thus, fewer people own larger areas of land.

Owing to the soybean expansion, the incorporation of new areas, and the displacement of the livestock to new regions, 3.7 million $\mathrm{Ha}$ were deforested between 2001 and 2012 (Socioenviromental Soybean Observatory, 2014). The consequence of this has been extensive flooding during the rainy season as well the loss of plants, insects and animal biodiversity, in addition to problems that have resulted from the increased use of herbicides and fertilizers (Altieri and Pengue, 2006). The aerial fumigation of toxic products is contaminating entire towns. The towns have organized themselves into a social movement called Fumigated Villages, and there is also a "Doctors of the Fumigated
Towns Network". They are developing studies and organizing protests against the agribusiness model of production. These populations are suffering spontaneous abortions, congenital malformations, cancers, and neurological problems because of the increasing use of agro-toxins (Doctors of the Fumigated Towns, 2010).

Despite the power of the transnational agribusiness corporations, Argentine communities have prevented the construction of the largest Monsanto GM seed plant in Latin America, which had been in construction in the Argentina town of Malvinas since 2013 (BBC, 2014). Prof. Lamm, an Argentine researcher and member of the Supreme Court of Mendoza, constituted the jury at the International Monsanto Tribunal at The Hague, where social movements condemned the company for "ecocide" (Pagina 12, 2017c).

The limits of the national development strategy based on the agribusiness model have become clear, in which soybean prices fell by half (from $\$ 650$ in 2012 to 329 in 2016) in the same way that all of the other commodities did. This constituted one of the factors of the redistribution dispute, the social convulsion and the neoliberal recovery of the 2015 election with the election of the right-wing candidate, Mauricio Macri.

\section{Conclusion}

Depicting the Argentine portion of the soybean commodity chain, I presented data on how the patterns of the world economy are reproduced. There is high monopolization and foreignization of soybean production and commercialization. Starting with landownership, as the census showed, there are fewer farms with higher acreage. The production is highly concentrated, with $2.6 \%$ of the producers controlling $50 \%$ of the total production. There are 10 leading exporters, the majority of which are transnational companies. In addition, six firms handle $93 \%$ of the crushing capacity. The US companies and other core countries companies have a large presence in the most profitable and monopolized nodes of soybean production and export. Thus, the core countries control the most profitable processes. It is important to note the increasing Chinese role in attempts to gain some of these spaces. As China has become a global player in genomics and agrochemicals, that is, buying Nidera, Syngenta, Atanor, producing $40 \%$ of the world supply of generic glyphosate, among others, the PRC has reproduced the same patterns as those of the core countries. Thus, China is not presenting a sustainable model for world food production.

Despite the friendly diplomatic statements of the PRC, there are important asymmetries in trade; for example, Argentine exports are highly concentrated on a few raw products, and the trade deficits have constantly increased. The soybean case is a representative example for an analysis of bilateral trade. A total of $68 \%$ of Argentine exports to China are concentrated on soy and it derivatives. Moreover, Chinese glyphosate is one of the leading products that is imported by Argentina. China is decreasing its soy oil imports and simultaneously increasing its production, which suggests that the country has a clear preference for buying raw materials at a lower value in favour of its own soy crushing industry. China's increasing trade with Argentina in the soybean sector follows the existing structure of a global commodity chain and does not offer much space for progressive change in Argentina's political economy. The presented data demystify expectations about China as an alternative globalizer that could bring greater benefits to the global South than the traditional core countries have.

The dilemma of the volatility of the commodity prices that were noted by Prebisch in the 1940s continues. Although exports have increased $84 \%$ in terms of volume from 2012 to 2015, the income 
in millions of dollars for the same period was 30\%. The fall in commodity prices confirms the importance of the US economy and macroeconomic policies and their impact on the world economy. The increase in world financial speculation and its crisis has influenced the accumulation process and the productive sector. The weakness and instability of commodity prices continue to be a structural characteristic of the world economy, fundamentally affecting the periphery and the semiperiphery.

The structural conditions in Argentina, and the semi-periphery status, still prevail in the economic, political and social spheres. The agrarian structure is similar to that of the 19th century in that the traditional families still have influential economic power. The contemporary globalization wave that began in the 1970s and consolidated in the 1990s has increased the role of the transnational companies in all of the nodes of the soybean commodity chain. However, at the same time, the Argentine state has promoted investments in science and technology in the agriculture business (such as the promotion of the biotechnological sector), encouraged national cooperatives and companies to increase their participation in soybean export, and blocked the legislation of IPR. Thus, the state has tried to avoid a periferization, conserving its semiperipheral status.

The Argentine soybean harvested area of $63 \%$ constitutes an entirely export-orientated commodity that has low domestic consumption. There are contradictions in the "progressist" government agenda such as the maintenance of the agribusiness development path based on the promotion of monoculture, which endangers environmental and human health and excludes small farmers, labourers, and indigenous people. Its structural limits have deepened with the falling prices of soybeans, the weak balance of payment equilibrium and the increasing disputes over the distribution of profits. The incapacity to change the structural conditioning to develop core activities is clear.

The CFK progressive government failed to stop soybean expansion, and, as a result of the drop in the economic growth rate that was associated with the falling commodity prices combined with the international block to obtaining financial credits because of the "Hedge fund" conflict, among other reasons, the government was put in check by various fronts: the conservative and transnational forces sought to retain their profitability and forced the government to make economic adjustments and an economic transfer to the concentrated sector to promote an increase in its profits. The poor economic performance generated discomfort among sections of the middle class. Social movements criticized the government for forgetting the socio-environmental issues and the consequences that are related to soybean crops. The distributive conflict increased the contribution to the social confusion that led to a right wing recovery in 2015, which resulted in the election of Mauricio Macri as the Argentine president, which has been considered to be a new neoliberal lunge.

The Macri's presidency did not suggest a clear strategy with regard to Chinese bilateral relations. During the first year of Macri's presidency, the government changed the yuan-SWAP into dollars (Pagina 12, 2015a), tried to stop and review infrastructure projects such as the two hydropower plants in the Patagonia that were financed by China (Pagina 12, 2015b), and sank a Chinese ship that was fishing illegally in Argentine waters (Pagina 12, 2016b). The Chinese investment projects had a default clause, which was that when one project is stopped, all projects will stop (Pagina 12, 2017b). Additionally, the PRC reduced its soybean imports from Argentina as a way to pressure the country. An economic report of the Argentine Agriculture Council in China showed that during the first 7 months of 2016, the PRC imported $4.1 \%$ more soybeans from other countries, and it diminished by $29 \%$ its soy imports from Argentina. To reverse this situation, president Macri visited China in May 2017 and resigned 10 agreements that China had already agreed with CFK and arranged 6 new deals (Pagina 12, 2017b). The Argentine strategy with regard to China is unclear and inclusive considering that Macri's company group, which is led by Franco Macri, the president's father, is one of the most important Chinese partners in Argentina, that is, it represents Chery and DFSK in the country (Clarin, 2017).

What will happen in the near future is uncertain. Nevertheless, I can identify some key factors that will influence the soybean commodity chain, such as Trump's macroeconomic policies that would probably increase US interest rates and the relative value of the dollar, which would hence affect commodity prices. Other factors include the current rate of Chinese growth, the contradictory bilateral relations between Argentina and China, and the inner social and political conflicts within Argentina, the United States and China, which may further compound this uncertainty.

\section{Notes}

1 The cycle involved (1) shifting political alliances: (a) national bourgeoisie with popular sectors; (b) pampean and large bourgeoisie; (2) each alliance's preferred economic policies, especially related to export restriction or promotion: a) Export restriction; increases real wages; ISI (Industrialization for imports substitution programs) $\rightarrow$ balance of payments crisis. (b) Increase exports; stabilization programs, spending cuts, anti-statism. $\rightarrow$ recession, stagflation+inflation. (3) the ensuing economic crisis that led to the new political alliance (Richardson, 2009).

2 Soybean prices experienced a "boom" between 2006 and 2012, achieving a price of US $\$ 650$ on the Chicago Board of Trade in August 2012 (La Nacion, 2012) that declined to $\$ 320$ in 2016 (World Bank, 2016). There is not complete agreement in the literature about the volatility of commodity prices. The soybean case cannot only be explained by the increasing and/or decreasing demand in China, as there was no abrupt change in demand during these years. Gosh (2010) and Bach (2014) explain that the prices were influenced by US macroeconomic policy, which led to a low purchasing power of the US dollar (2002-2007 and 2009-2011) as well as the expansive monetary policies of the US Federal Reserve in a context of low investment and weak economic growth after the 2007/2008 financial crisis, which led to a flood of money in the futures markets of raw materials offering a privileged place for its speculative "investment". The valorization of the dollar since 2012 led to the drop in commodity prices.

3 Bilateral Agreement states: “(...) Whereas the Parties have the purpose of promoting actions to strengthen the bilateral economic relation between both countries, seeking to equilibrate the trade balance of that relation through the development of investments that allow increasing Argentina's demand and productive capacity (...) Whereas the Parties acknowledge the need of the Argentine Republic to improve its export position (...)" (Argentina, 2014).

4 In 1996, Carlos Menem’s Agriculture Secretary, Mr Solá, authorized the entry of GM soybean in an express process, based of environmental studies by Monsanto.

5 While most of the studies on CC do not analyze any specific nation-state case, I chose to concentrate on the Argentine portion of the soybean commodity chain (APSCC) because it permits us to understand how international actors play in a specific context and how national actors construct different strategies. I draw the CC and present a panorama of the distribution of gains based on secondary data.

6 Soybean prices obtained from Grimaldi Grassi S.A. Brokers, 2016.

7 Soybean prices change constantly; thus, it is difficult to precisely determine the amounts and share by agents in each segment. Nevertheless, these data present a panorama of the actors and the degree of monopolization and foreignization of the sector.

8 Latin America is leading the ranking of concentration of land, $1 \%$ of landowners owned half of the continent. The GINI is 0.79 , which is much higher than Europe (0.57), Africa (0.56) and Asia (0.55) (Pagina 12, 2017a).

9 Confirmed Chinese Purchases or Leases of Latin American Land: Cuba (8.259 Ha); Venezuela (3.185 Ha); Brazil (16.800 Ha); Bolivia (12.488 Ha); Jamaica (27.800 Ha) (Myers et al., 2015; Inter-American Dialog, 2015).

10 Bayer bought Monsanto in 2016, concentrating much more on the genomics sector, in which the leading 4 companies Monsanto-Bayer, Syngenta-ChemChina, DowDuPont and BASF concentrate 59.8\% (Greenpeace, 2017).

11 These projects have stopped by the Macri administration and now they are going to be re-discussed.

\section{References}

Ainsuain O (2008) Del genocidio y robo de tierras al boom sojero. Rosario: Editorial Universidad de Rosario. 
Altieri A and Pengue W (2006) GM soybean: Latin America's new colonizer. Seedling. January, https://www.grain.org/article/entries/588-gm-soybean-latinamerica-s-new-colonizer.

Amnesty International. (2016) Indigenous Territory, http://www.territorioindi gena.com.ar/.

Argentina. (2014) Framework agreement for economic and investment cooperation, http://tratados.mrecic.gov.ar/.

Arrighi G and Drangel J (1986) The stratification of the world-economy: An exploration of the semipheral zone. Review; $\mathbf{X}$ (Summer): 9-74.

Bach P (2014) Causas que explican la caída del precio de las materias primas, http://www.laizquierdadiario.com/Causas-que-explican-la-caida-del-precio-delas-materias-primas.

Bair J (2005) Global capitalism and commodity chains: Looking back, going forward. Competition and Change; 9 (2): 153-180.

BBC Mundo. (2014) Argentina. 12/12/2014. Malvinas Argentinas, la comunidad que logró frenar a Monsanto, el gigante de los transgénicos.Veronica Smink, http://www.bbc.com/mundo/noticias/2014/12/141128_argentina_transgenicos_ monsanto_vs.

Blázquez-Lidoy J, Rodríguez J and Santiso J (2007) Angel or Devil? China's Trade Impact on Latin American Emerging Markets. The Visible Hand of China in Latin America. OCDE: Paris, France.

CAFMA. (2015) La Industria de la Maquinaria Agrícola en la Argentina 2015, http://www.cafma.org.ar/cafma/la-industria-de-la-maquinaria-agricola-en-laargentina-2015/.

Calzada J and Corina S (2015) Los márgenes brutos en soja de primera apenas alcanzan para pagar alquileres. Informativo seminal Nro. 1696, https://www.bcr. com.ar/Pages/Publicaciones/infoboletinsemanal.aspx?IdArticulo $=1206$.

CEI International Economy Center. (2007) Argentina bilateral trade with China. Ministry of Foreign Affairs of Argentina, http://www.agrichina.org/page.aspx? id $=8$.

CEI International Economy Center. (2008) Argentina bilateral trade with China. Ministry of Foreign Affairs of Argentina, http://www.agrichina.org/page.aspx? id $=8$.

CEI International Economy Center. (2009) Argentina bilateral trade with China. Ministry of Foreign Affairs of Argentina, http://www.agrichina.org/page.aspx? id $=8$.

CEI International Economy Center. (2011) Argentina bilateral trade with China. Ministry of Foreign Affairs of Argentina, http://www.agrichina.org/page.aspx? id $=8$.

Clarin. (2014) 11/15/2014. Fuerte inversión china en Atanor, https://www.clarin. com/rural/Fuerte-inversion-china-Atanor_0_S1qDW-d9vXx.html.

Clarin. (2017) Los Macri suman otra marca china de vehículos, https://www.clarin. com/ieco/economia/macri-suman-marcha-china-vehiculos_0_Byp50af8e.html, accessed 10 January 2017.

CONICET, Consejo Nacional de Investigaciones Científicas y Técnicas, IMHICIHU. (2012) Buenos Aires, http://www.imhicihu-conicet.gob.ar/ARGENTI NAenMAPAS/caste/intr.ht, accessed 1 March 2015.

CRA Confederaciones Rurales Argentina. (2015) CRA se refirió a los anuncios de exportación de carne a Estados Unidos, http://www.cra.org.ar/0/vnc/nota.vnc? id $=14965$.

Dabat G and Paz (2013) La paradoja de la soja. Buenos Aires: Centro Cultural de la Cooperación.

Doctors of the Fumigated Towns. (2010) First report of the Doctors of the Fumigated Towns. Medicine Faculty, Cordoba National University. 27-28 August, Ciudad Universitaria, Córdoba.

FAO. (2016) Food and Agriculture Organization of the United Nations. Database on soybeans, http://www.fao.org/faostat/en/\#data/QC, accessed 7 May 2016.

Fascendini F (2006) El boom sojero deja dramáticas consecuencias en Argentina, http://www.rebelion.org/noticia.php?id = 39482, accessed 17 October 2006.

Fiancial Times. (2016) China's Cofco buys remainder of grain trader Nidera, 23 August, https://www.ft.com/content/29596026-9b83-3652-9d64-7b903d0873c4.

Filomeno FA (2014) Monsanto and Intellectual Property in South America. Palgrave Macmillan: UK.

Fried A (2012) Estrategias de competitividad y valor agregado para los aceites de soja y girasol. Seminario de agronegocio 07/20/2012, Universidad del CEMA.

Fumigated Towns. (2012) Encuentro Nacional de los Pueblos Fumigados (2012) Declaración del 2do. Encuentro Nacional de Pueblos Fumigados. Declaración, http://www.juicioalafumigacion.com.ar/declaracion-del-2do-encuentro-nacio nal-de-pueblos-fumigados/.

Ghosh J (2010) The unnatural coupling: Food and global finance. Journal of Agrarian Change; 10 (1): 72-86.?

Giancola SI, Salvador ML, Covacevich M and Iturrioz G (2009) Análisis de la cadena de la soja en Argentina. Rev. Estudios Socioeconómicos de los Sistemas Agroalimentarios y Agroindustriales Nro. 3. Instituto Nacional de Tecnología Agropecuaria, INTA.

GRAIN. (2015) Argentina: Nuevos transgénicos "nacionales". Las resistencias se multiplican, https:/www.grain.org/article/entries/5357-argentina-nuevos-trans genicos-nacionales-las-resistencias-se-multiplican.
Greenpeace. (2017) Ley de semillas: Del campo al plato, el lobby de las empresas quimicas, http://www.greenpeace.org/argentina/Global/argentina/2017/3/ INFORME-Ley-de-semillas-30-vinculos-entre-el-Gob-y-las-agroquimicas.pdf.

Grosso S, Bellini ME, Qüesta L, Guibert M, Lauxmann S and Rotondi F (2010) Impactos de los "pools de siembra" en la estructura social agraria: Una aproximación a las transformaciones en los espacios centrales de la provincia de Santa Fe (Argentina). Revista de estudios regionales y mercado de trabajo (6), 115-138. En Memoria Académica, http://www.memoria.fahce.unlp.edu.ar/art_ revistas/pr.4537/pr.4537.pdf

Hilton CW (2012) Monsanto \& the Global Glyphosate Market: Case Study. June 2012, http://www.wiglafjournal.com/pricing/2012/06/monsanto-the-global-gly phosate-market-case-study/.

Hopkins T and Wallerstein IM (1977) Patterns of development of the modern world-system. Review; 1 (2): 11-145.

Hopkins T and Wallerstein IM (1986) Commodity chains in the world-economy prior to 1800. Review (Fernand Braudel Center); 10 (1)Anniversary Issue: The Work of the Fernand Braudel Center (Summer) 157-170.

Hopkins T and Wallerstein IM (1994) Commodity chains: Construct and research. In: Gereffi G and Korzeniewicz M (eds). Commodity Chains and Global Capitalism. Praeger: Westport, CT.?.

INDEC. (2015) National Statistics and Census Institute. Argentine Trade Exchange, http://www.indec.gob.ar/nivel4_default.asp?id_tema_1=3\&id_tema_ $2=2 \&$ id tema $3=40$, accessed 5 June 2016 .

INDEC. (2016) National Statistics and Census Institute. Economy, http://www indec.gob.ar/bases-de-datos.asp, accessed 3 August 2017

Infocampo. (2016) Aseguran que la soja sigue siendo la opción más rentable en relación al maíz, http://www.infocampo.com.ar/aseguran-que-la-soja-siguesiendo-la-opcion-mas-rentable-en-relacion-al-maiz/, accessed 16 August 2016.

Infocampo. (2017) Para la Sociedad Rural de Rafaela, hoy "lo único rentable es la soja”, http://www.infocampo.com.ar/para-la-sociedad-rural-de-santa-fe-hoy-lounico-rentable-es-la-soja/, accessed 15 February 2017.

Ishida A, Law S and Aita Y (2003) Changes in food consumption expenditure in Malaysia. Agribusiness; 19 (2003): 61-76.

Jenkins R and Dussel P (eds) (2009) China and Latin America: economic relations in the twenty-first century. Deutsches Institut für Entwicklungspolitk in cooperation with Universidad Nacional Autónoma de México (UNAM) / Centro de Estudios China-México (CECHIMEX). - Bonn: DIE Deutsches Institut für Entwicklungspolitik. ISBN 978-3-88985-485-8, http://edoc.vifapol. de/opus/volltexte/2013/4389/pdf/Studies_49.pdf.

Jones E, Akbay C, Roe B and Chern WS (2003) Analyses of consumers' dietary behaviour: An application of the AIDS model to supermarket scanner data. Agribusiness; 19 (2003): 203-221.

La Nacion. (2012) Nuevo récord de la soja en Chicago y mejores precios para la cosecha local, http://www.lanacion.com.ar/1505419-nuevo-record-de-la-sojaen-chicago-y-mejores-precios-para-la-cosecha-local, accessed 9 May 2012.

La Nacion. (2014) Una empresa estatal china se quedó con el 51\% de la cerealera Nidera, http://www.lanacion.com.ar/1667735-una-empresa-estatal-china-sequedo-con-el-51-de-la-cerealera-nidera, accessed 23 February 2014.

La Nacion. (2016) Flexibilizan la ley de tierras para extranjeros, http://www. lanacion.com.ar/1914668-flexibilizan-la-ley-de-tierras-para-extranjeros, accessed 2 July 2016.

Lederman D, Cravino J and Olarreaga M (2006a) Foreign Direct Investment in Latin America During the Emergence of China and India: Stylized Facts: Background Paper for the Office of the Chief Economist for Latin America and the Caribbean Regional Study: Latin America Respond to the Growth of China and India. World Bank: Washington DC.

Lederman D, Cravino J and Olarreaga M (2006b) Substitution between Foreign Capital in China, India and the Rest of the World: Much Ado About Nothing: Background Paper for the Office of the Chief Economist for Latin America and the Caribbean Regional Study: Latin America Respond to the Growth of China and India. World Bank: Washington DC.

Liu H, Parton K, Zhou Z and Cox R (2009) 'At-home meat consumption in China: An empirical study'. Australian Journal of Agricultural and Resource Economics; 53 (4): 485-501.

MECON. (2011) Ministry of Economy and Public Finance. Oilseeds complex, http://www.mecon.gov.ar/peconomica/docs/Complejo_Oleaginoso.pdf, accessed 4 August 2015

Ministry of Finance. (2016) Informes de Cadenas de Valor: Maquinaria Agrícola http://www.economia.gob.ar/peconomica/docs/Complejo_Maquinaria_Agri cola.pdf.

Ministry of Foreign Affairs. (2015) Digital Library of international agreements, http://tratados.mrecic.gov.ar.

Myers M, Jie M and Jie G (2015) China's Agricultural Investment in Latin America: A Critical Assessment. China and Latin American Report. Inter-American Dialog: Washington DC, http://www.iica.int/sites/default/files/events/presenta tions/2015-10/chinas-agricultural-investment-in-latin-america.pdf. 
Nacht PA (2012) El Dragón en América Latina: las relaciones económicocomerciales y los riesgos para la región. Íconos. Revista de Ciencias Sociales. Num. 45, Quito, septiembre 2013, pp. 141-154.

O’Donnell G (1978) State and alliances in Argentina, 1956-1976. J. Dev; 15 (1): $3-33$.

Pagina 12. (2003) Polémica productores vs Monsanto-Atanor. Una pelea que no es china. Mario Raiteri Presidente de Coninagro, http://www.pagina12.com.ar/ diario/suplementos/cash/17-724-2003-05-11.html, accessed 11 May 2003.

Pagina 12. (2015a) Los yuanes ya no son papelitos de colores, https:// www.pagina12.com.ar/diario/economia/2-288857-2015-12-23.html, accessed 23 December 2015

Pagina 12. (2015b) Macri evalúa parar las represas, https://www.pagina12. com.ar/diario/economia/2-289114-2015-12-28.html, accessed 28 December 2015.

Pagina 12. (2016a) Abren la tranquera para eludir la ley de tierras, https://www. pagina12.com.ar/diario/economia/2-303227-2016-07-02.html, accessed 2 July 2016.

Pagina 12. (2016b) Un pesquero chino que no contó el cuento, http://www. pagina12.com.ar/diario/elpais/1-294680-2016-03-16.html, accessed 16 March 2016.

Pagina 12. (2016c) Tironean de las semillas, https://www.pagina12.com.ar/diario/ economia/2-291822-2016-02-05.html, accessed 5 February 2016.

Pagina 12. (2017a) Distribución de la tierra en América Latina. Reforma Agraria, https://www.pagina12.com.ar/34818-reforma-agraria, accessed 2 May 2017.

Pagina 12. (2017b) Temer Arribas, https://www.pagina12.com.ar/38914-temerarribas, accessed 20 May 2017.

Pagina 12. (2017c) Eleonora Lamm: No podemos seguir viendo cómo grandes empresas destruyen el planeta, https://www.pagina12.com.ar/32389-eleonoralamm-no-podemos-seguir-viendo-como-grandes-empresas, accessed 17 May 2017

Prebisch R (1964) Nueva Política Comercial para el Desarrollo. Fondo de Cultura Económica: México D.F.

Regmi A, Deepak MS, Seale Jr JL and Bernstein J (2001) Cross-country analysis of food consumption patterns. In: Regmi A (ed). Changing Structure of Global Food Consumption and Trade. ERS WRS No. 01-1 USDA: Washington DC.

Regunaga M (2009) Implications of the organization of the commodity production and processing industry. Case Studies in Latin America and the Caribbean Region: The Soybean Chain in Argentina. World Bank.

Reuters. (2016) ChemChina just made the biggest foreign purchase in Chinese history, http://www.businessinsider.com/chemchina-buying-syngenta-for-43billion-2016-2, accessed 3 February 2016.

Richardson NP (2009) Export-oriented populism: Commodities and coalitions in Argentina. Studies in Comparative International Development; 44, 228-255.

Richardson NP (2012) The Politics of Abundance:?Export Agriculture and Redistributive Conflict in South America. Dissertation in Political Science. Berkeley University.

Rural Land. (2016). Ministry of Justice and Human Rights (Argentina), http:// www.jus.gob.ar/tierras-rurales/tramites.aspx, accessed 30 February 2017.

Robinson W (2008) Latin America and Global Capitalism: A Critical Globalization Perspective. Baltimore: John Hopkins University Press.

Slipak A (2013) La relación entre China y América Latina en la discussión sobre el modelo de desarrollo de la región: hacia economias reprimarizadas, http:// media.wix.com/ugd/b9eda6_33914f9824044c7670c5c4d1165e1100.pdf, accessed 14 October 2014.

Slipak A (2014) América Latina y China: jcooperación Sur-Sur o "Consenso de Beijing”. Nueva Sociedad Democracia y Política en América Latina No 250, março-abril 2014, p.102-113, http://nuso.org/articulo/america-latina-y-chinacooperacion-sur-sur-o-consenso-de-beijing/, accessed 20 May 2015.

Slipak A and Bolinga L (2015) El Consenso de Beijing y la reprimarización productiva de América Latina: el caso argentino. Revista Problemas del Desarrollo; 183 (46): 33-58.

Socioenviromental Soybean Observatory. (2014) El monocultivo de la soja en el cono sur de Sudamérica, aportes para un manejo responsable, http:// observatoriosoja.org/el-monocultivo-de-soja-en-el-cono-sur-de-sudamericaaportes-para-un-manejo-responsable/, accessed 25 February 2015

Soyatech. (2016) Soya facts. http://www.soyatech.com/soy_facts.htm, accessed 3 April 2016.

Strada J and Vila IA (2015) La producción de soja en Argentina: causas e impactos de su expansión. Centro cultural de la cooperación. Ed. 23 Estudios de Economía Política y Sistema Mundial, http://www.centrocultural.coop/revista/ articulo/550/.

Svampa M (2013) Consenso de los Commodities' y lenguajes de valoración en América Latina. Nueva Sociedad No 244, 3-4/2013, www.nuso.org/upload/ articulos/3926_1.pdf.

Telam. (2014) Soja y poder económico: el negocio, http://www.telam.com.ar/ informes-especiales/1-soja-y-poder-economico/2-el-negocio, accessed $7 \mathrm{March}$ 2015.

Telam. (2015) Macri anunció "retenciones cero para las exportaciones regionales", http://www.telam.com.ar/notas/201512/129967-mauricio-macri-anuncia-enpergamino-medidas-para-productores.html, accessed 14 December 2015.

USDA United States Department of Agriculture. (2015) Foreign Agricultural Service, https://apps.fas.usda.gov/psdonline/.

Wang J and Zhou Z (2005) Animal product consumption. In: Zhou Z and Tian WM (eds). Grains in China: Food grain, Feedgrain and World Trade. Ashgate: Aldershot, UK, pp 87-107.

World Bank. (2016) Data Bank, http://databank.worldbank.org/data/home.aspx accessed 3 February 2017

Zhou Z, Tian W, Wang J, Liu H, Cao L (2012) Food Consumption Trends in China. Report submitted to the Australian Government Department of Agriculture, Fisheries and Forestry.

\section{Data availability}

The datasets analysed during the current study are available in the Dataverse repository: http://dx.doi.org/10.7910/DVN/DAV4EI. All data were originally obtained from publicly accessible websites.

These datasets were derived from the following public domain resources: Argentine National Statistic Institute INDEC http://www.indec.gov.ar National Agricultural CENSUS. http://www.indec.gov.ar/nivel4_default.asp?id_tema_1 $=3$ \&id_tema_2 $=8$ \&id_tema_3 $=87$ USDA United States Department of Agriculture Foreign Agricultural Service https://apps.fas.usda.gov/psdonline/app/index.html\#/app/advQuery Argentine Ministry of Finance http://www.economia.gob.ar TELAM, Argentine National Press Agency, 2014. http://www.telam.com.ar Worldbank http://databank.worldbank.org/ddp/ home

\section{Additional information}

Competing interests: The author declares that there are no competing financial interests.

Reprints and permission information is available at http://www.palgrave-journals.com/ pal/authors/rights_and_permissions.html

How to cite this article: Sly MJH (2017) The Argentine portion of the soybean commodity chain. Palgrave Communications. 3:17095 doi: 10.1057/palcomms.2017.95.

Publisher's note: Springer Nature remains neutral with regard to jurisdictional claims in published maps and institutional affiliations.

This work is licensed under a Creative Commons Attribution 4.0 International License. The images or other third party material in this article are included in the article's Creative Commons license, unless indicated otherwise in the credit line; if the material is not included under the Creative Commons license, users will need to obtain permission from the license holder to reproduce the material. To view a copy of this license, visit http://creativecommons.org/licenses/by/4.0/

(C) The Author(s) 2017 